\title{
PENERAPAN METODE MIND MAPPING UNTUK MENINGKATKAN KEMAMPUAN PEMAHAMAN KONSEP MATEMATIS MAHASISWA PADA MATA KULIAH KALKULUS I
}

\author{
Erma Monariska \\ Universitas Suryakancana \\ ermamonariska@gmail.com
}

\begin{abstract}
ABSTRAK
Matematika memiliki struktur keterkaitan yang kuat dan jelas antara konsep-konsepnya sehingga aspek yang penting didalam pembelajaran matematika adalah pemahaman terhadap konsep itu sendiri. Untuk itu diperlukan suatu upaya yang mampu mengakomodir kemampuan pemahaman konsep secara lebih bermakna, yaitu metode yang memberikan keleluasaan, kebebasan dan kesempatan yang luas bagi mahasiswa calon guru untuk mengkonstruk pengetahuan dan pemahamannya sendiri, salahsatunya yaitu dengan metode mind mapping. Mind mapping merupakan teknik mencatat kreatif melalui penggambaran simbol, kata-kata, warna, panah dan garis pada selembar kertas berdasarkan ide pikiran mahasiswa dengan mengungkapkan inti-inti penting materi pembelajaran yang menggambarkan keterkaitan antar konsep secara menyeluruh sehingga memudahkan mahasiswa dalam mengingat dan memahami konsep-konsep matematika secara lebih bermakna. Penelitian ini merupakan penelitian eksperimen dengan menggunakam instrumen penelitian berupa hasil tes kemampuan awal matematis, tes pemahaman konsep matematis, dan angket skala sikap. Penelitian ini dilakukan pada mahasiswa Program Studi Pendidikan Matematika Universitas Suryakancana. Berdasarkan hasil penelitian, diketahui bahwa : 1) Peningkatan kemampuan pemahaman konsep matematis mahasiswa yang menggunakan mind mapping lebih baik daripada siswa yang menggunakan pembelajaran konvensional; 2) Peningkatan kemampuan pemahaman konsep matematis mahasiswa yang menggunakan mind mapping lebih baik daripada siswa yang menggunakan pembelajaran konvensional dilihat dari kemampuan awal matematis (rendah, sedang, dan tinggi); 3) Mahasiswa memiliki sikap positif terhadap penggunaan metode mind mapping.
\end{abstract}

Kata kunci : Mind Mapping, Kemampuan Pemahaman Konsep Matematis

\section{PENDAHULUAN}

Matematika merupakan ilmu mengenai struktur yang mencakup hubungan, pola, maupun bentuk. Matematika berkenaan dengan ide-ide (gagasan-gagasan), struktur-struktur dan hubungannya diatur secara logis sehingga matematika berkaitan dengan konsep-konsep yang abstrak yang tersusun secara hierarkis dan penalarannya deduktif sehingga pemahaman konsep matematis menjadi sangat penting. Belajar konsep merupakan hal yang paling mendasar dalam proses belajar matematika, oleh karena itu seorang pendidik dalam mengajarkan konsep harus beracuan pada sebuah tujuan yang harus dicapai. Konsep matematika yang sangat kompleks, akan cukup sulit bahkan tidak bisa dipahami jika pemahaman konsep yang lebih sederhana belum memadai. 
Sejalan dengan pernyataan tersebut, NCTM menyebutkan bahwa pemahaman matematis merupakan aspek yang sangat penting dalam prinsip pembelajaran matematika. Oleh karena itu didalam proses pembelajaran harus disertai pemahaman. Hal ini merupakan tujuan utama dari belajar matematika sehingga belajar dengan pemahaman tersebut harus terus ditekankan didalam kurikulum (Qohar, $2010: 1$ ).

Pemahaman konsep adalah yang berupa penguasaan sejumlah materi pelajaran, dimana peserta didik tidak sekedar mengenal dan mengetahui, tetapi mampu mengungkapkan kembali konsep dalam bentuk yang lebih mudah dimengerti serta mampu mengaplikasikannya (Rosmawati, 2008: 5). Pembelajaran matematika tidak hanya dilakukan dengan mentransfer pengetahuan kepada peserta didik, akan tetapi untuk membantu peserta didik menanamkan konsep secara benar.

Selanjutnya, NCTM (2000 : 233) menyatakan bahwa pemahaman matematis akan lebih bermakna jika dibangun oleh siswa sendiri. Untuk itu, diperlukan suatu upaya yang inovatif yang memberikan kebebasan dan kesempatan kepada mahasiswa calon guru untuk secara aktif mengkonstruksi sendiri pemahamannya. Salah satunya yaitu dengan menerapkan metode mind mapping dalam pembelajaran matematika.

Menurut Edward (2009 : 64) mind mapping adalah cara paling efektif dan efisien untuk memasukkan, menyimpan dan mengeluarkan data dari, atau masuk ke dalam otak. Mind mapping merupakan salah satu cara mencatat materi pelajaran yang memudahkan peserta didik untuk belajar. Mind mapping juga dikategorikan sebagai teknik mencatat kreatif, yang dengan teknik itu akan memudahkan peserta didik dalam mengingat konsepkonsep matematika sehingga diharapkan akan dapat membantu mahasiswa untuk menguasai dan memahami konsep-konsep matematika secara lebih bermakna sehingga mahasiswa tidak hanya dapat menggunakan tetapi juga menyampaikan kembali informasi-informasi tersebut. Oleh karena itu, peneliti ingin mengetahui sejauh mana peningkatan kemampuan mahasiswa melalui metode mind mapping terhadap kemampuan pemahaman konsep matematis melalui penelitian yang berjudul "Penerapan Metode Mind Mapping untuk Meningkatkan kemampuan Pemahaman Konsep Matematis Mahasiswa pada Mata Kuliah Kalkulus I".

Berdasarkan latar belakang masalah diatas, maka permasalahan tersebut dijabarkan sebagai berikut :

1. Apakah peningkatan kemampuan pemahaman konsep matematis mahasiswa yang memperoleh pembelajaran dengan metode mind mapping lebih baik dibandingkan 
dengan mahasiswa yang memperoleh pembelajaran dengan metode konvensional?

2. Apakah peningkatan kemampuan pemahaman konsep matematis mahasiswa yang memperoleh pembelajaran dengan metode mind mapping lebih baik dibandingkan dengan mahasiswa yang memperoleh pembelajaran dengan metode konvensional dilihat dari kemampuan awal mahasiswa (rendah, sedang, dan tinggi)?

3. Bagaimana sikap mahasiswa terhadap pembelajaran dengan menggunakan metode mind mapping?

\section{METODE PENELITIAN}

Penelitian ini merupakan penelitian eksperimen dengan populasinya adalah mahasiswa Program Studi Pendidikan Matematika Universitas Suryakancana dan sampelnya dipilih secara purposif. Instrumen penelitian yang digunakan dalam penelitian ini berupa tes kemampuan awal matematis, tes pemahaman konsep matematis, dan angket skala sikap mahasiswa.

\section{HASIL PENELITIAN DAN PEMBAHASAN}

\section{Analisis Data Kemampuan Awal Matematis (KAM) Mahasiswa}

Kemampuan Awal Mahasiswa (KAM) diperoleh dari skor tes prasyarat mata kuliah Kalkulus I. Tujuannya untuk mengetahui kesetaraan sampel penelitian serta peringkat mahasiswa berdasarkan kategori rendah, sedang, dan tinggi dengan kriteria pengelompokkan mahasiswa menurut Arikunto (2013:299) yang disajikan pada tabel 1 . Selanjutnya data skor tes KAM ini digunakan sebagai variabel pengontrol untuk melihat kemampuan pemahaman konsep matematis mahasiswa

Tabel 1. Kriteria Pengelompokkan KAM

\begin{tabular}{cl}
\hline Nilai & Kriteria \\
\hline$K A M<\bar{x}-s$ & Mahasiswa Kelompok Rendah \\
$\bar{x}-s \leq K A M<\bar{x}+s$ & Mahasiswa Kelompok Sedang \\
$K A M \geq \bar{x}+s$ & Mahasiswa Kelompok tinggi \\
\hline
\end{tabular}

Berdasarkan hasil perhitungan terhadap nilai KAM dengan bantuan aplikasi program ANATES Versi 4 diperoleh data kategori KAM pada kelompok eksperimen yang berjumlah 25 mahasiswa, terdiri dari 4 mahasiswa kelompok rendah, 16 mahasiswa kelompok sedang dan 5 mahasiswa kelompok tinggi. Sedangkan kelompok kontrol yang berjumlah 26 mahasiswa, terdiri dari 5 mahasiswa kelompok rendah, 17 mahasiswa kelompok sedang dan 4 mahasiswa kelompok tinggi. 


\section{Analisis Data skor Pretes Kemampuan Pemahaman Konsep Matematis}

Skor pretes kemampuan pemahaman konsep matematis mahasiswa adalah skor yang diperoleh sebelum pembelajaran diberikan kepada mahasiswa, baik kelas eksperimen maupun kelas kontrol. Berdasarkan pengolahan data terhadap skor pretes pada aspek kemampuan pemahaman konsep matematis, rerata skor pretes kemampuan pemahaman konsep matematis pada kelas eksperimen dan kelas kontrol relatif tidak ada perbedaan. Skor rerata pretes kemampuan pemahaman konsep matematis pada kelas eksperimen adalah 12,08 atau $30 \%$ dari skor ideal dengan simpangan baku 6,76, sedangkan skor rerata kelas kontrol adalah 12,35 atau 31\% dari skor ideal dengan simpangan baku 5,94. Dengan demikian dapat disimpulkan bahwa skor rerata pretes pada kelas kontrol lebih baik daripada kelas eksperimen, karena rerata lebih besar dari kelas eksperimen.

Untuk mengetahui ada atau tidak adanya perbedaan yang signifikan antara skor pretes kemampuan pemahaman konsep matematis mahasiswa kelas eksperimen dan kelas kontrol maka dilakukan analisis statistik pengujian perbedaan rerata dua sampel independen dengan menggunakan software SPSS versi 20. Analisis statistik pengujian perbedaan rerata dua sampel diawali dengan uji normalitas dan homogenitas varians. Uji normalitas yang digunakan adalah uji Kolmogorov-Smirnov, dengan kriteria : jika Sig > 0,05, maka sebaran data berdistribusi normal. Hasil perhitungan uji normalitas disajikan pada Tabel 2.

Tabel 2. Uji Normalitas Data Skor Pretes

\begin{tabular}{lcccc}
\hline \multirow{2}{*}{ Kelas } & \multicolumn{3}{c}{ Kolmogorov-Smirnov } & \multirow{2}{*}{ Keterangan } \\
\cline { 2 - 4 } & Statistik & Dk & Signifikan & \\
\hline Eksperimen & 0,127 & 25 & 0,200 & Normal \\
Kontrol & 0,128 & 26 & 0,200 & Normal \\
\hline
\end{tabular}

Berdasarkan hasil perhitungan uji normalitas Kolmogorov-Smirnov yang disajikan pada Tabel 2, nilai signifikan kelas eksperimen dan kelas kontrol >0,05, sehingga dapat disimpulkan bahwa data skor pretes mahasiswa pada kelas eksperimen dan kelas kontrol berasal dari populasi yang berdistribusi normal.

Uji homogenitas varians skor pretes mahasiswa pada kelas eksperimen dan kelas kontrol pada kelas eksperimen dan kelas kontrol menggunakan Uji Levene. Hasil perhitungannya disajikan pada Tabel 3.

Tabel 3. Uji Homogenitas Varians Data Skor Pretes

\begin{tabular}{crcc}
\hline Levene Statistic & df & df2 & Signifikan \\
\hline 0,812 & 1 & 49 & 0,372 \\
\hline
\end{tabular}


Berdasarkan hasil perhitungan uji homogenitas varians skor pretes kemampuan pemahaman konsep matematis yang disajikan pada Tabel 3, nilai signifikan >0,05. Hal ini menunjukkan bahwa data skor pretes pada kelas eksperimen dan kelas kontrol mempunyai varians homogen. Kedua data skor pretes kemampuan pemahaman konsep matematis mempunyai varians homogen dan berdistribusi normal, maka untuk mengetahui perbedaan rerata dua sampel dihitung dengan Uji-t.

Hipotesis yang akan diuji adalah $\mathrm{H}_{0}$ : tidak terdapat perbedaan rata-rata skor pretes antara kelas eksperimen dan kelas kontrol, dan $\mathrm{H}_{\mathrm{a}}$ : terdapat perbedaan rata-rata skor pretes antara kelas eksperimen dan kelas kontrol. Berdasarkan kriteria pengujian : jika $-t_{\text {tabel }} \leq t_{\text {hitung }}$ $\leq \mathrm{t}_{\text {tabel}}$, maka $\mathrm{H}_{0}$ diterima, dan jika $-\mathrm{t}_{\text {hitung }}<-\mathrm{t}_{\text {tabel }}$ atau $\mathrm{t}_{\text {hitung }}>\mathrm{t}_{\text {tabel }}$ maka $\mathrm{H}_{0}$ ditolak (Priyatno dalam Septian, 2012). Hasil perhitungan disajikan dalam Tabel 4.

Tabel 4. Uji Rerata Skor Pretes

\begin{tabular}{ccc}
\hline $\mathrm{t}_{\text {hitung }}$ & $\mathrm{t}_{\text {tabel }}$ & Keterangan \\
\hline$-0,149$ & 2,010 & $\mathrm{H}_{0}$ diterima \\
\hline
\end{tabular}

Berdasarkan hasil perhitungan rerata dua sampel dengan Uji-t yang disajikan pada Tabel 4, karena data skor pretes mahasiswa homogen maka menggunakan Equal Variances Assumed (diasumsikan varians sama). Sehingga diperoleh nilai $t_{\text {hitung }}=-0,149$, karena $t_{\text {tabel }}$ pada signifikan 0,05:2=0,025 (uji dua pihak) dengan derajat kebebasan $n-2$ atau $51-2=$ 49, maka diperoleh $\mathrm{t}_{\text {tabel }}=2,010$. Karena $-2,010 \leq-0,149 \leq 2,010$, maka $\mathrm{H}_{0}$ diterima. Dengan demikian dapat disimpulkan bahwa tidak terdapat perbedaan rata-rata skor pretes mahasiswa antara kelas eksperimen dan kelas kontrol.

Hasil tersebut menunjukkan bahwa mahasiswa yang terlibat dalam penelitian ini, baik dari kelas eksperimen maupun kelas eksperimen memiliki KAM yang relatif sama. Kondisi ini tentunya berpengaruh terhadap kesiapan mahasiswa dalam menerima materi mata kuliah Kalkulus I yang akan disampaikan melalui pembelajaran mind mapping dan pembelajaran konvensional. Hal ini sesuai dengan pendapat Arends (dalam Septian, 2012), yang menyatakan bahwa proses awal peserta didik dalam mempelajari ide-ide baru bergantung dari pengetahuan awal mereka dan struktur kognitif yang sudah ada sebelumnya. 


\section{Analisis Peningkatan Kemampuan Pemahaman Konsep Matematis Mahasiswa}

Peningkatan kemampuan pemahaman konsep matematis mahasiswa dilihat dengan membandingkan skor pretes dan skor postes, yang dihitung dengan rumus g faktor (gain skor ternormalisasi) menurut Meltzer (dalam Septian, 2012) sebagai berikut :

Keterangan :

$$
g=\frac{S_{a k h i r}-S_{a w a l}}{S_{\text {maks }}-S_{\text {awal }}}
$$

$S_{a k h i r}=$ skor postes

$S_{\text {awal }}=$ skor pretes

$S_{\text {maks }}=$ skor maksimum

Tabel 5. Kriteria Gain

\begin{tabular}{cc}
\hline Gain $(\mathrm{g})$ & Kriteria \\
\hline $\mathrm{g}>0,7$ & Tinggi \\
$0,3<\mathrm{g} \leq 0,7$ & Sedang \\
$\mathrm{g} \leq 0,3$ & Rendah \\
\hline
\end{tabular}

Berdasarkan pengolahan data terhadap skor pretes, postes dan peningkatan (N-Gain) kemampuan pemahaman konsep matematis mahasiswa, diperoleh skor rerata dan deviasi standar

Tabel 6. Statistik Deskripsi Skor Gain ternormalisasi Kemampuan Pemahaman Konsep Matematis Dilihat dari Keseluruhan dan Kategori KAM Mahasiswa

\begin{tabular}{cllccccc}
\hline \multirow{2}{*}{ Pembelajaran } & Kategori & \multicolumn{2}{c}{ Pretes } & \multicolumn{2}{c}{ Postes } & \multicolumn{2}{c}{ N-Gain } \\
\cline { 2 - 8 } & KAM & Mean & SD & Mean & SD & Mean & SD \\
\hline \multirow{3}{*}{ Eksperimen } & Rendah & 2,75 & 2,22 & 22,25 & 1,71 & 0,53 & 0,17 \\
\cline { 2 - 8 } & Sedang & 11,38 & 4,08 & 28,00 & 2,03 & 0,58 & 0,50 \\
\cline { 2 - 8 } & Tinggi & 21,80 & 1,10 & 35,00 & 1,73 & 0,73 & 0,88 \\
\cline { 2 - 8 } Kontrol & Total & 12,08 & 6,76 & 28,48 & 4,35 & 0,60 & 0,87 \\
\hline & Rendah & 4,00 & 2,55 & 19,80 & 1,79 & 0,44 & 0,57 \\
\cline { 2 - 8 } & Sedang & 12,65 & 3,22 & 25,65 & 1,69 & 0,47 & 0,58 \\
\cline { 2 - 8 } & Tinggi & 21,50 & 1,29 & 33,25 & 1,50 & 0,64 & 0,69 \\
\cline { 2 - 8 } & Total & 12,35 & 5,94 & 25,69 & 4,33 & 0,49 & 0,87 \\
\hline
\end{tabular}

Dari Tabel 6 menunjukkan skor rerata pretes kemampuan pemahaman konsep matematis, antara mahasiswa pada setiap kategori KAM (rendah, sedang, tinggi) pada kelas eksperimen dengan setiap kategori KAM (rendah, sedang, tinggi) pada kelas kontrol, relatif tidak terdapat perbedaan, hal ini menunjukkan bahwa kemampuan pemahaman konsep matematis mahasiswa secara keseluruhan maupun kategori KAM mahasiswa sebelum diberikan perlakuan mempunyai kemampuan pemahaman konsep matematis yang relatif tidak terdapat perbedaan. 
Selanjutnya pada Tabel 6 menunjukkan bahwa faktor pembelajaran (secara keseluruhan) cenderung memberikan pengaruh terhadap kemampuan pemahaman konsep matematis mahasiswa, jika dilihat dari N-Gain tes kemampuan pemahaman konsep matematis. Berdasarkan faktor pembelajaran (secara keseluruhan), rerata N-Gain tes kemampuan pemahaman konsep matematis mahasiswa yang menggunakan mind mapping dalam pembelajaran matematika cenderung memperoleh $\mathrm{N}$-Gain yang lebih baik dibandingkan dengan mahasiswa yang memperoleh pembelajaran konvensional. Demikian juga berdasarkan kategori KAM mahasiswa, rerata N-Gain kategori KAM mahasiswa tinggi cenderung memperoleh N-Gain lebih baik daripada kategori KAM mahasiswa sedang dan rendah dan rerata N-Gain kategori KAM mahasiswa sedang cenderung memperoleh N-Gain lebih baik daripada kategori KAM mahasiswa rendah.

Uji statistik untuk mengetahui peningkatan kemampuan pemahaman konsep matematis yang lebih baik antara mahasiswa yang menggunakan mind mapping dalam pembelajaran matematika dan mahasiswa yang memperoleh pembelajaran konvensional dilihat dari keseluruhan dan kategori kemampuan awal matematis mahasiswa dilakukan dengan menggunakan software SPSS versi 20. Yang diawali dengan uji normalitas dan uji homogenitas varians. Uji normalitas yang digunakan adalah uji Kolmogorov-Smirnov, dengan kriteria : jika sig > 0,05, maka sebaran data berdistribusi normal. Hasil perhitungan uji normalitas disajikan pada Tabel 7.

Tabel 7. Uji Normalitas Rerata N-Gain Kemampuan Pemahaman Konsep Matematis Ditinjau dari Keseluruhan dan Kategori KAM Mahasiswa

\begin{tabular}{llcccc}
\hline \multirow{2}{*}{ Kelas } & \multirow{2}{*}{ Kategori KAM } & \multicolumn{3}{c}{ Kolmogorov-Smirnov } & \multirow{2}{*}{ Keterangan } \\
\cline { 3 - 5 } Eksperimen & & Statistik & Dk & Signifikan & \\
& Rendah & 0,364 & 4 & 0,100 & Normal \\
& Sedang & 0,201 & 16 & 0,085 & Normal \\
& Tinggi & 0,336 & 5 & 0,066 & Normal \\
& Keseluruhan & 0,173 & 25 & 0,053 & Normal \\
\hline \multirow{3}{*}{ Kontrol } & Rendah & 0,286 & 5 & 0,200 & Normal \\
& Sedang & 0,199 & 17 & 0,071 & Normal \\
& Tinggi & 0,230 & 4 & 0,100 & Normal \\
& Keseluruhan & 0,098 & 26 & 0,200 & Normal \\
\hline
\end{tabular}

Berdasarkan hasil perhitungan uji normalitas Kolmogorov-Smirnov yang disajikan pada Tabel 7, kelas eksperimen dan kelas kontrol secara keseluruhan dan untuk setiap kategori Kemampuan Awal Matematis (rendah, sedang, tinggi) mempunyai nilai signifikan > 0,05 maka sebaran data berdistribusi normal. 
Selanjutnya dilakukan uji homogenitas varians N-Gain kemampuan pemahaman konsep matematis untuk keenam kelompok sampel tersebut dengan Uji Levene. Hasil perhitungan disajikan pada Tabel 8.

Tabel 8. Uji Homogenitas Varians Skor N-Gain Kemampuan Pemahaman Konsep Matematis

\begin{tabular}{cccc}
\hline Levene Statistic & dk1 & dk2 & Signifikan \\
\hline 0,017 & 1 & 49 & 0,897 \\
\hline
\end{tabular}

Dari Tabel 8, nilai rerata Levene Statistic adalah 0,017 dan nilai signifikansinya adalah 0,897 > 0,05. Dengan demikian dapat disimpulkan bahwa varians populasi N-Gain kemampuan pemahaman konsep matematis yang memperoleh pembelajaran dengan metode mind mapping dan pembelajaran konvensional adalah homogen.

Untuk melihat ada atau tidak adanya perbedaan N-Gain (peningkatan skor kemampuan pemahaman konsep matematis dari sebelum diberikan perlakuan hingga sesudah diberikan perlakuan) secara signifikan, dilihat dari keseluruhan dan kategori KAM mahasiswa, maka digunakan teknik statistik parametrik yaitu Anova Dua Jalur.

Hipotesis yang akan diuji adalah $\mathrm{H}_{01}$ : tidak terdapat perbedaan peningkatan kemampuan pemahaman konsep matematis antara mahasiswa yang memperoleh pembelajaran mind mapping dan pembelajaran konvensional, $\mathrm{H}_{02}$ : tidak terdapat perbedaan peningkatan kemampuan pemahaman konsep matematis antara mahasiswa dengan kategori KAM (rendah, sedang, tinggi), $\mathrm{H}_{03}$ : tidak terdapat interaksi antara pembelajaran dengan kategori KAM (rendah, sedang, tinggi), $\mathrm{H}_{\mathrm{a} 1}$ : terdapat perbedaan peningkatan kemampuan pemahaman konsep matematis antara mahasiswa yang memperoleh pembelajaran mind mapping dan pembelajaran konvensional, $\mathrm{H}_{\mathrm{a} 2}$ : terdapat perbedaan peningkatan kemampuan pemahaman konsep matematis antara mahasiswa dengan kategori KAM (rendah, sedang, tinggi), $\mathrm{H}_{\mathrm{a} 3}$ : terdapat interaksi antara pembelajaran dengan kategori KAM (rendah, sedang, tinggi). Kriteria pengujian : jika nilai signifikan > 0,05 maka $\mathrm{H}_{0}$ diterima, dan jika signifikan $<0,05$ maka $\mathrm{H}_{0}$ ditolak. Hasil perhitungan Anova disajikan pada Tabel 9.

Tabel 9. Anova Peningkatan Kemampuan Pemahaman Konsep Matematis Mahasiswa

\begin{tabular}{lrrrrrc}
\hline \multicolumn{1}{c}{ Sumber } & \multicolumn{1}{c}{ Total } & Ku & $\begin{array}{c}\text { Rerata } \\
\text { Kuadrat }\end{array}$ & \multicolumn{1}{c}{ F } & \multicolumn{1}{c}{ Sig. } & $\mathrm{H}_{0}$ \\
\hline Corrected Model & 0,366 & 5 & 0,073 & 21,741 & 0,000 & \\
Intercept & 11,167 & 1 & 11,167 & 3318,687 & 0,000 & \\
Pembelajaran & 0,078 & 1 & 0,078 & 23,042 & 0,000 & Tolak \\
KAM & 0,219 & 2 & 0,109 & 32,487 & 0,000 & Tolak \\
Pembelajaran *KAM & 0,001 & 2 & 0,000 & 0,100 & 0,905 & Terima \\
Total & 15,595 & 51 & & & & \\
Corrected Total & 0,517 & 50 & & & & \\
\hline
\end{tabular}


Berdasarkan hasil pengolahan data yang disajikan pada Tabel 9, dapat disimpulkan bahwa untuk pembelajaran memiliki nilai signifikan 0,000. Karena nilai sig $=0,000<0,05$, maka $\mathrm{H}_{01}$ ditolak. Hal ini menunjukkan bahwa terdapat perbedaan yang signifikan peningkatan kemampuan pemahaman konsep matematis antara mahasiswa yang menggunakan pembelajaran mind mapping dan pembelajaran konvensional (secara keseluruhan). Dengan kata lain, antara mahasiswa yang menggunakan pembelajaran mind mapping dalam pembelajaran matematika dan pembelajaran konvensional terdapat perbedaan yang signifikan dalam peningkatan kemampuan pemahaman konsep matematis mahasiswa.

Meskipun kualitas N-Gain kemampuan pemahaman konsep matematis mahasiswa pada kelas eksperimen dan kelas kontrol termasuk kategori sedang, namun rerata N-Gain kemampuan pemahaman konsep matematis mahasiswa yang menggunakan mind mapping lebih baik daripada rerata N-Gain kemampuan pemahaman konsep matematis yang memperoleh pembelajaran konvensional. Hal ini dikarenakan mind mapping merupakan produk kreatif yang dihasilkan peserta didik dalam kegiatan belajarnya yang dibuat dengan kata-kata, simbol, ataupun gambar yang mereka pahami sehingga membantu mahasiswa merekam dan mengaitkan konsep yang telah dipelajari untuk menyelesaikan permasalahan matematika dengan berusaha mengaitkan berbagai konsep dalam matematika. Pembelajaran mind mapping juga turut membantu mahasiswa dalam memahami konsepkonsep matematika secara bermakna. Hal ini sesuai dengan pendapat Buzan (2008: 4) yang menyatakan bahwa mind mapping adalah suatu cara mencatat kreatif, efektif yang secara harfiah akan memetakan pikiran-pikiran. Demikian pula menurut Edward (2009: 64) mind mapping adalah cara paling efektif dan efisien untuk memasukkan, menyimpan dan mengeluarkan data dari, atau masuk kedalam otak. Lebih lanjut, Hudojo (2002: 9) juga mengatakan bahwa mind mapping adalah keterkaitan antara konsep suatu materi pelajaran yang direpresentasikan dalam jaringan konsep yang dimulai dari inti permasalahan sampai pada bagian pendukung yang mempunyai hubungan satu dengan lainnya, sehingga dapat membentuk pengetahuan dan mempermudah pemahaman suatu topik pelajaran.

Kemampuan Awal Matematis (KAM) mahasiswa memiliki signifikan 0,000, karena nilai sig $=0,000<0,05$, maka $\mathrm{H}_{02}$ ditolak. Hal ini menunjukkan bahwa terdapat perbedaan yang signifikan dalam peningkatan kemampuan pemahaman konsep matematis antara mahasiswa yang menggunakan pembelajaran mind mapping dan pembelajaran konvensional 
dilihat dari kemampuan awal matematis mahasiswa (rendah, sedang, tinggi). Sehingga dapat disimpulkan bahwa faktor kemampuan awal matematis mahasiswa memberikan pengaruh yang signifikan terhadap peningkatan kemampuan pemahaman konsep matematis.

Pembelajaran*KAM memiliki nilai signifikan 0,661, karena nilai sig $=0,661>0,05$, maka $\mathrm{H}_{03}$ diterima. Hal ini menunjukkan bahwa tidak terdapat interaksi antara pembelajaran dengan KAM mahasiswa, sehingga dapat disimpulkan bahwa untuk faktor peningkatan kemampuan pemahaman konsep matematis mahasiswa, tidak terdapat interaksi antara faktor pembelajaran dengan KAM mahasiswa.

Interaction plot peningkatan kemampuan pemahaman konsep matematis mahasiswa disajikan pada Gambar 1.

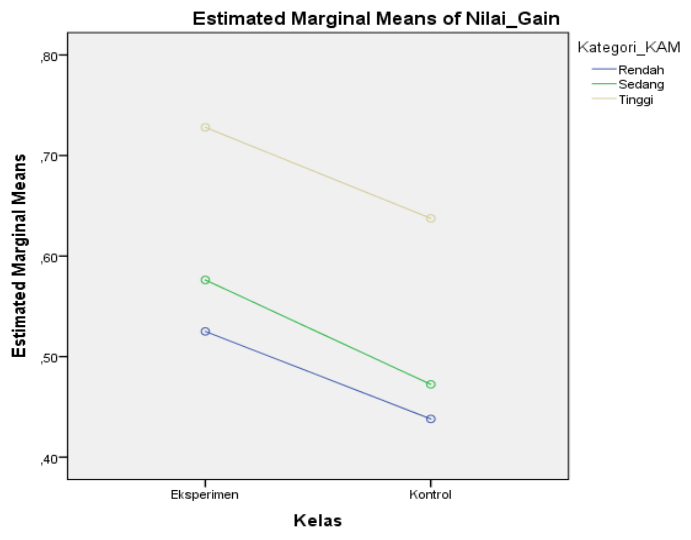

Gambar 1. Plot Interaksi antara KAM Mahasiswa dan Pembelajaran dalam Peningkatan Kemampuan Pemahaman Konsep Matematis

Berdasarkan Gambar 1, terlihat bahwa mahasiswa pada kelas eksperimen yang menggunakan mind mapping dalam pembelajaran matematika dengan kategori KAM mahasiswa tinggi peningkatan kemampuan pemahaman konsep matematisnya lebih baik daripada mahasiswa yang menggunakan pembelajaran konvensional. Begitupun dengan kategori KAM mahasiswa sedang dan rendah, kelas eksperimen peningkatan kemampuan pemahaman konsep matematisnya lebih baik daripada kelas kontrol.

Berdasarkan hasil perhitungan yang disajikan pada Tabel 9, terdapat perbedaan yang signifikan peningkatan kemampuan pemahaman konsep matematis antara mahasiswa yang menggunakan metode mind mapping dan pembelajaran konvensional dilihat dari keseluruhan, maka untuk mengetahui peningkatan kemampuan pemahaman konsep matematis mana yang lebih baik akan digunakan Uji-t satu pihak (Uji pihak kanan). 
Hipotesis yang akan diuji adalah $\mathrm{H}_{0}: \mu_{1}=\mu_{2}, H_{a}: \mu_{1}>\mu_{2}$. Kriteria pengujian : jika $t_{\text {hitung }}$ $\geq t_{\text {tabel }}$, maka $\mathrm{H}_{0}$ ditolak. Hasil perhitungannya disajikan pada Tabel 10 .

Tabel 10. Uji Satu Pihak N-Gain Kemampuan Pemahaman Konsep Matematis

\begin{tabular}{rcc}
\hline $\mathrm{t}_{\text {hitung }}$ & $\mathrm{t}_{\text {tabel }}$ & Keterangan \\
\hline 4,402 & 2,010 & $\mathrm{H}_{0}$ ditolak \\
\hline
\end{tabular}

Berdasarkan hasil perhitungan rerata dua sampel dengan Uji-t yang disajikan pada Tabel 10, menggunakan Equal Variances Assumed (diasumsikan varians sama). Sehingga diperoleh nilai $t_{\text {hitung }}=4,402$, karena $t_{\text {tabel }}$ pada signifikan $0,05: 2=0,025$ (uji dua pihak) dengan derajat kebebasan $n-2$ atau $51-2=49$, maka diperoleh $t_{\text {tabel }}=2,010$. Karena 4,402 $>$ 2,010, maka $\mathrm{H}_{0}$ ditolak. Dengan demikian dapat disimpulkan bahwa secara keseluruhan peningkatan kemampuan pemahaman konsep matematis mahasiswa yang mengunakan metode mind mapping dalam pembelajaran matematika lebih baik daripada peningkatan kemampuan pemahaman konsep matematis mahasiswa yang memperoleh pembelajaran konvensional.

Berdasarkan hasil perhitungan Anova dua jalur, terdapat perbedaan yang signifikan dalam peningkatan kemampuan pemahaman konsep matematis mahasiswa dilihat dari kategori KAM mahasiswa (rendah, sedang, tinggi). Untuk mengetahui peningkatan kemampuan permahaman konsep matematis yang lebih baik dilihat dari kategori KAM mahasiswa (rendah, sedang, tinggi), dilakukan Uji Post Hoc Tukey. Hasil perhitungannya disajikan pada Tabel 11.

Tabel 11. Hasil Uji Tukey Rerata Skor N-Gain Kemampuan Pemahaman Konsep Matematis Berdasarkan Kategori KAM

\begin{tabular}{cccc}
\hline PK 1 (I) & PK 2 (J) & Perbedaan Rerata (I-J) & Signifikan \\
\hline Tinggi & Rendah & 0,2111 & 0,000 \\
& Sedang & 0,1651 & 0,000 \\
\hline Sedang & Rendah & 0,0461 & 0,099 \\
\hline
\end{tabular}

Pada Tabel 11, terlihat bahwa nilai signifikan untuk pasangan KAM mahasiswa tinggi dan rendah serta pasangan KAM mahasiswa tinggi dan sedang adalah 0,000 $<0,05$. Perbedaan rerata KAM mahasiswa tinggi dan rendah adalah 0,2111 , dan perbedaan rerata KAM mahasiswa tinggi dan sedang adalah 0,1651. Artinya, bahwa secara signifikan rerata peningkatan kemampuan pemahaman konsep matematis pada kategori KAM mahasiswa tinggi lebih baik daripada peningkatan kemampuan pemahaman konsep matematis pada kategori KAM mahasiswa rendah dan sedang. Selanjutnya, nilai signifikan untuk pasangan KAM mahasiswa sedang dan rendah adalah 0,099>0,05. Perbedaan rerata KAM mahasiswa 
sedang dan rendah adalah 0,0461. Artinya, bahwa secara signifikan rerata peningkatan kemampuan pemahaman konsep matematis pada kategori KAM mahasiswa sedang dan rendah tidak ada perbedaan.

Secara rinci peningkatan kemampuan pemahaman konsep matematis pada kelas eksperimen dan kelas kontrol dapat dilihat pada Tabel 12.

Tabel 12. Rekapitulasi Rerata Peningkatan Pemahaman Konsep Matematis Mahasiswa

\begin{tabular}{lcccc}
\hline \multicolumn{1}{c}{ Kelas } & Rerata Pretes & Rerata Postes & Rerata N-Gain & Kategori \\
\hline Eksperimen & 12,08 & 28,48 & 0,60 & Sedang \\
Kontrol & 12,35 & 25,69 & 0,49 & Sedang \\
\hline
\end{tabular}

Dari Tabel 12, peningkatan pemahaman konsep matematis pada kelas eksperimen berdasarkan rerata skor gain ternormalisasi pada kemampuan pemahaman konsep matematis adalah 0,60 dengan kategori sedang. Sedangkan pada kelas kontrol, rerata gain ternormalisasi pada pemahaman konsep matematis adalah 0,49 dengan kategori sedang.

\section{Analisis Sikap Mahasiswa terhadap Penerapan Metode Mind Mapping}

Data skala sikap yang telah terkumpul, dihitung dan ditabulasikan serta dihitung rata-rata seluruh jawaban. Data hasil skala sikap diperoleh dari 26 siswa pada kelas eksperimen. Pengisian skala sikap dilakukan setelah pembelajaran dan tes akhir selesai. Data yang diperoleh adalah skala sikap mahasiswa terhadap penerapan metode mind mapping dalam pembelajaran matematika dan skala sikap mahasiswa terhadap pemahaman konsep matematis (Tabel 13).

Tabel 13. Distribusi Sikap Mahasiswa Terhadap Penerapan Metode Mind Mapping dan Pemahaman Konsep Matematis

\begin{tabular}{|c|c|c|}
\hline Sikap & Pernyataan & $\begin{array}{l}\text { Rerata Skor } \\
\quad \text { Sikap }\end{array}$ \\
\hline \multirow{4}{*}{$\begin{array}{l}\text { Sikap mahasiswa } \\
\text { terhadap penerapan } \\
\text { metode Mind } \\
\text { Mapping dalam } \\
\text { pembelajaran } \\
\text { matematika }\end{array}$} & $\begin{array}{l}\text { Pembelajaran matematika dengan menggunakan mind } \\
\text { mapping membuat saya lebih memahami setiap konsep } \\
\text { matematika yang dipelajari }\end{array}$ & 3,48 \\
\hline & $\begin{array}{l}\text { Pembelajaran mind mapping membuat saya sulit } \\
\text { memahami konsep-konsep matematika secara benar }\end{array}$ & 3,16 \\
\hline & $\begin{array}{l}\text { Pembelajaran matematika dengan mind mapping } \\
\text { memudahkan saya mengaitkan suatu konsep ke konsep } \\
\text { yang lainnya }\end{array}$ & 3,36 \\
\hline & $\begin{array}{l}\text { Pembelajaran dengan menggunakan mind mapping } \\
\text { membuat saya bingung mengaitkan konsep-konsep } \\
\text { matematika }\end{array}$ & 3,28 \\
\hline
\end{tabular}


Pembelajaran dengan mind mapping memotivasi saya untuk belajar lebih giat lagi dalam memahami konsepkonsep matematika secara benar Pembelajaran dengan menggunakan mind mapping membuat saya jenuh dan tidak berkembang

Pembelajaran dengan mind mapping membantu dan 3,48 memperkuat saya dalam merekam dan mengingat konsep yang telah dipelajari

Pembelajaran dengan mind mapping membuat saya sulit mengingat konsep-konsep matematika yang telah dipelajari

Pembelajaran dengan mind mapping membuat saya mampu menyelesaikan setiap permasalahan matematika dalam kehidupan sehari-hari secara sistematis

Pembelajaran mind mapping membuat saya tidak berusaha menyelesaikan permasalahan matematika dengan menggunakan konsep-konsep matematika

\begin{tabular}{|c|c|c|}
\hline \multirow{13}{*}{$\begin{array}{l}\text { Sikap mahasiswa } \\
\text { terhadap } \\
\text { pemahaman } \\
\text { konsep matematis }\end{array}$} & \multirow[b]{2}{*}{$\begin{array}{l}\text { Rata-rata } \\
\text { Dalam menyelesaikan masalah baru, saya berusaha } \\
\text { menghubungkannya dengan masalah sebelumnya, dan } \\
\text { jika terdapat teknik yang sama maka saya } \\
\text { menggunakannya }\end{array}$} & \multirow[b]{2}{*}{$\frac{3,36}{4,32}$} \\
\hline & & \\
\hline & $\begin{array}{l}\text { Saya sulit mengaitkan berbagai konsep dalam } \\
\text { matematika }\end{array}$ & 2,48 \\
\hline & $\begin{array}{l}\text { Saya menyelesaikan soal matematika sesuai dengan } \\
\text { contoh di buku }\end{array}$ & 4,00 \\
\hline & $\begin{array}{l}\text { Dalam menjawab suatu masalah yang sulit, saya tidak } \\
\text { pernah berusaha mencari contoh yang sama atau yang } \\
\text { lebih sederhana dari permasalahan untuk memperoleh } \\
\text { pemahaman kearah penyelesaian }\end{array}$ & 4,12 \\
\hline & $\begin{array}{l}\text { Saya dapat menyatakan ulang suatu konsep matematika } \\
\text { yang telah dipelajari }\end{array}$ & 3,52 \\
\hline & $\begin{array}{l}\text { Saya sulit menjelaskan masalah matematika dengan } \\
\text { hasil yang jelas dan ringkas }\end{array}$ & 3,00 \\
\hline & $\begin{array}{l}\text { Saya dapat memberika alasan atau bukti terhadap } \\
\text { kebenaran suatu pernyataan matematika yang saya } \\
\text { sepakati }\end{array}$ & 3,88 \\
\hline & $\begin{array}{l}\text { Saya sulit menyajikan suatu masalah secara sistematis } \\
\text { dalam berbagai bentuk }\end{array}$ & 2,64 \\
\hline & $\begin{array}{l}\text { Dalam menyelesaikan soal matematika, saya } \\
\text { menuliskan terlebih dahulu data yang diketahui dan } \\
\text { ditanyakan, setelah itu masuk pada penyelesaian soal } \\
\text { matematika }\end{array}$ & 4,64 \\
\hline & $\begin{array}{l}\text { Saya sulit menyelesaikan permasalahan matematika } \\
\text { yang berhubungan dengan masalah sehari-hari }\end{array}$ & 3,04 \\
\hline & Rata-rata & 3,56 \\
\hline & Rata-Rata Keseluruhan & 3,46 \\
\hline
\end{tabular}


Sikap siswa terhadap penerapan metode mind mapping dalam pembelajaran matematika dan terhadap pemahaman konsep matematis menunjukkan sikap positif. Sikap positif tersebut ditunjukkan dari hasil analisis skor skala sikap mahasiswa yang lebih besar daripada skor sikap netralnya $(3,46>3,00)$. Ini berarti sikap mahasiswa terhadap penerapan metode mind mapping dalam pembelajaran matematika dan terhadap pemahaman konsep matematis menunjukkan sikap positif.

Berdasarkan hasil analisis skala sikap dapat diambil kesimpulan bahwa mahasiswa memiliki sikap positif terhadap penggunaan metode mind mapping dan kemampuan pemahaman konsep matematis. Hal ini terlihat dari rata-rata skor sikap mahasiswa terhadap penggunaan metode mind mapping dan kemampuan pemahaman konsep matematis yang melebihi skor netralnya. Namun berdasarkan pernyataan-pernyataan dalam skala sikap tersebut, ada dua pernyataan yang rerata skor sikapnya kurang dari skor netralnya yaitu pernyataan nomor 2 dan nomor 7 . Namun dua pernyataan tersebut secara rerata tidak mempengaruhi hasil daripada sikap mahasiswa terhadap penggunaan metode mind mapping dan kemampuan pemahaman konsep matematis mahasiswa yang tetap menunjukkan sikap positif karena reratanya masih tetap melebihi skor netralnya. Kedua pernyataan tersebut secara tidak langsung mengungkapkan bahwa mahasiswa mengalami kesulitan dalam mengaitkan berbagai konsep dalam matematika dan mahasiswa juga mengalami kesulitan dalam menyajikan masalah secara sistematis kedalam berbagai bentuk representasi. Oleh karena itu, kedua permasalahan ini perlu mendapat perhatian serius untuk segera diatasi mengingat sangat pentingnya kedua kemampuan itu bagi mahasiswa dalam memahami konsep matematika secara lebih bermakna.

\section{KESIMPULAN}

1. Peningkatan kemampuan pemahaman konsep matematis mahasiswa yang memperoleh pembelajaran dengan metode mind mapping lebih baik dibandingkan dengan mahasiswa yang memperoleh pembelajaran dengan metode konvensional.

2. Peningkatan kemampuan pemahaman konsep matematis mahasiswa yang memperoleh pembelajaran dengan metode mind mapping lebih baik dibandingkan dengan mahasiswa yang memperoleh pembelajaran dengan metode konvensional dilihat dari kemampuan awal matematis mahasiswa

3. Mahasiswa memiliki sikap yang positif terhadap penggunaan metode mind mapping. 


\section{REFERENSI}

Arikunto, S. (2013). Prosedur Penelitian : Suatu Pendekatan Praktik. Jakarta : Rineka Cipta.

Buzan, Tony. (2008). Buku Pintar Mind Map. Jakarta: Gramedia Pustaka Utama.

Edward, Caroline. (2009). Mind mapping untuk Anak sehat dan Cerdas. Yogyakarta : Sakti.

Hudojo, H.,et al. (2002). Peta Konsep. Jakarta: Makalah disajikan dalam Forum Diskusi Pusat Perbukuan Depdiknas. [Online]. Tersedia: http://nintya sintya. blogspot.co.id/2013/09/metode-mind-map.html?m=1, diakses pada 25 Januari 2017.

NCTM (National Council of Teacher of Mathematics). (2000). Principles and Standars forSchool Mathematics. Reston, Virginia: The National Council of Teacher of Mathematics,Inc. [Online]. Tersedia: http://www.nctm.org., diakses pada 10 Januari 2017.

Qohar, Abd. (2010). Mengembangkan Kemampuan Pemahaman, Koneksi dan Komunikasi Matematis serta Kemandirian Belajar Matematika Siswa SMP melalui Reciprocal Learning. Disertasi UPI pada PPs UPI : tidak dipublikasikan.

Rosmawati. (2008). Penggunaan Teknik Probing untuk Meningkatkan Pemahaman Konsep Matematis Siswa. Skripsi : UPI.

Septian, Ari. (2012). Penggunaan Weblog dalam Pembelajaran Matematika Untuk Meningkatkan Kemampuan Koneksi Matematis Mahasiswa. Tesis : UNPAS. 